\title{
DYNAMICS OF A TEMPERATE FLUVIAL ESTUARY IN EARLY WINTER
}

\author{
N. VAZ \\ J.M. DIAS \\ I. MARTINS
}

\author{
Physics Department \\ University of Aveiro \\ Campus de Santiago \\ 3810-193 Aveiro, Portugal
}

*to whom all correspondence should be addressed

e-mail: nuno@fis.ua.pt
Selected from papers presented in $9^{\text {th }}$ International Conference on Environmental Science and Technology (9CEST2005)

1-3 September 2005, Rhodes island, Greece

\begin{abstract}
In order to evaluate how current speed, salinity and water temperature stratification behaves under the influence of a freshwater source in a tidal domain, a 25 hour survey campaign was performed in the upper sector of the Vouga River estuary, the major source of freshwater of Ria de Aveiro, a coastal lagoon located in the Northwest of the Iberian Peninsula.
\end{abstract}

The sampling campaign started at 10:30 AM of January $15^{\text {th }} 2004$ and ended next day, covering two tidal cycles, during neap tide condition (tidal range of about $1.7 \mathrm{~m}$ ) and low river runoff $\left(58 \mathrm{~m}^{3} \mathrm{~s}^{-1}\right)$. Observations of the thermohaline properties and currents were undertaken at an anchor station located about $9 \mathrm{~km}$ upstream of the mouth of the lagoon. Local meteorological variables were also measured.

Vertically lunar hourly profiles of salinity, water temperature and current speed were obtained and the results indicate that the estuary is forced by semi-diurnal tides. The profiles of current intensity indicated an asymmetry between flood $(\mathbf{v}>0)$ and ebb $(\mathbf{v}<0)$ being the ebb currents higher than the flood ones, with maximum values of about -1.1 and $0.7 \mathrm{~m} \mathrm{~s}^{-1}$, respectively. The major ebbing velocity was enhanced by the freshwater runoff. The lunar hourly variations of salinity and water temperature reveal that during the ebb, the vertical stratification decreases, increasing during the flood period. The salinity ranges between 0 and 32 psu and the water temperature between 10.9 and $13.7^{\circ} \mathrm{C}$. Near the surface, the water temperature is influenced by the air temperature, decreasing along the day. At mid-water and near the bed the salinity and water temperature increases during the flood periods, decreasing during the ebb. From the time mean salinity and current profiles for the 25 hours period were obtained the stratification and circulation parameters of the classical Stratification-Circulation Diagram (Hansen and Rattray, 1966), revealing that the estuary can be considered partially mixed-highly stratified.

KEYWORDS: circulation, salinity, water temperature, stratification, fluvial estuary, coastal lagoon, Vouga River, Ria de Aveiro

\section{INTRODUCTION}

An estuary is a semi-enclosed body of water having a free connection with the open sea and within which sea water is diluted with freshwater derived from land drainage [1]. More commonly, for oceanographers, engineers and natural scientists an estuary is an important and sensible area of interaction between fresh and salt water. These areas can, generally, be divided in three areas: (a) a marine or lower estuary, (b) a middle 
estuary and an (c) upper or fluvial estuary characterised by freshwater but subject to a daily tidal action [2].

The upper fluvial estuary of the Vouga River is located near the east boundary of the central area of Ria de Aveiro (fig. 1), a remarkable coastal lagoon located in the Northwest coast of the Iberian Peninsula $\left(40^{\circ} 38^{\prime} \mathrm{N}, 8^{\circ} 44^{\prime} \mathrm{W}\right)$. Ria de Aveiro is a temperate, mesotidal and shallow costal lagoon. More than 300000 people live around the lagoon and its channels. This concentration of people as well as industry, agriculture, fisheries and tourism in such a small area arises several environmental problems. The knowledge of the physical characteristics of the water mass of an estuary represents an enormous contribution to the protection, management and sustentation of these natural environments.

Ria de Aveiro has a mean depth of about $1 \mathrm{~m}$ (over the local datum) except in navigation channels, were dredging operations are frequently carried out. It is characterised by a large number of narrow channels particularly in its central area (fig. 1) and large intertidal areas, namely mud flats and salt marshes. The tides are mainly semi-diurnal and they represent the major driving force of circulation in the lagoon [3].

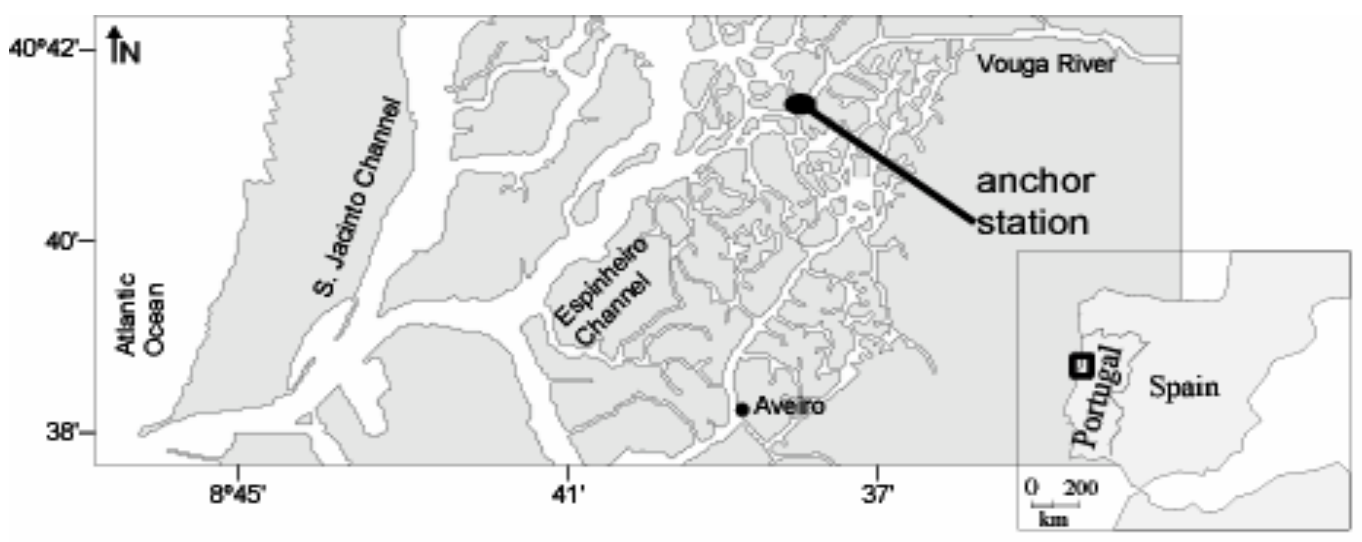

Figure 1. Study area with the location of the anchor station

Vouga River represents the major source of freshwater discharging into the lagoon [4] and it is connected to the sea by a $10 \mathrm{~km}$ east-west oriented channel (Espinheiro Channel). It discharges into Ria de Aveiro through a long (about $3200 \mathrm{~m}$ ) and narrow channel (about $60 \mathrm{~m}$ wide) (Rio Novo do Príncipe) with depth of about $5 \mathrm{~m}$. This freshwater source is determinant in the establishment of the salinity patterns of this lagoon. Nevertheless, there are no systematic measurements allowing a complete description of its influence. There is a study by Vicente [5] presenting freshwater values of $3400 \mathrm{~m}^{3} \mathrm{~s}^{-1}$ correspondent to flood flows for a period of 25 years. The average flow for Vouga River is referred by Borrego et al [6] as $25 \mathrm{~m}^{3} \mathrm{~s}^{-1}$, but according to Vicente [5] this value is underestimated. During the period from September 2003 to September 2004, measurements of the Vouga River's incoming flow were performed in the frame of this work and the annual averaged flow value found was $31.45 \mathrm{~m}^{3} \mathrm{~s}^{-1}$. The higher river flow values occurred during the Autumn and the beginning of the Winter with a maximum of $143.16 \mathrm{~m}^{3} \mathrm{~s}^{-1}$ in January. The minimum flows occur during the dryer seasons with values ranging from $30 \mathrm{~m}^{3} \mathrm{~s}^{-1}$ (early Spring) to $2.0 \mathrm{~m}^{3} \mathrm{~s}^{-1}$ (late Summer). The total estimated freshwater input for the lagoon is very small (about $1.8 \times 10^{6} \mathrm{~m}^{3}$ during a complete tidal cycle) [7] when compared with the tidal prism at the mouth of the lagoon: $136.7 \times 10^{6}$ and $34.9 \times 10^{6} \mathrm{~m}^{3}$, at extreme spring and extreme neap tides, respectively [4]. Although, the small contribution of the discharging rivers in terms of water input, when compared to the tidal prism, they may have a long-term influence in the residual transport [8].

The main objectives of this study are: a) to evaluate how the current speed, salinity and water temperature stratification behaves under the influence of a freshwater source, 
based on a two tidal cycles sampling campaign and b) perform the estuary classification based on the Hansen and Rattray circulation and stratification theory [9]. The measurements were performed in early winter (January $15^{\text {th }}$ ) at an anchor station located in the upper sector of the Vouga River estuary $\left(40^{\circ} 41^{\prime} \mathrm{N}, 8^{\circ} 39^{\prime} \mathrm{W}\right)$ in neap tide condition and low river runoff $\left(58 \mathrm{~m}^{3} \mathrm{~s}^{-1}\right)$.

\section{METHODOLOGY}

Lunar hourly vertical profiles of thermohaline properties and current speed were simultaneously measured with a SAIV A/S mini STD model SD204 and a self recording current meter Valeport model 105, respectively, over two tidal cycles at an anchor station (fig. 1), during neap tide. The vertical sampling of salinity, water temperature and current velocity was performed using a time step of $1 \mathrm{~s}$. The STD instrument measures water temperature using a Thermistor in a range from -2 to $40^{\circ} \mathrm{C}$ with an accuracy of $+/-0.01$ ${ }^{\circ} \mathrm{C}$. The water pressure is measured using a Piezoresistive sensor with an accuracy of $+/-$ $0.02 \%$ of the depth $(500 \mathrm{~m})$ and for the conductivity the instrument uses an Inductive cell in a range of 0 to $70 \mathrm{mS} \mathrm{cm}{ }^{-1}$ with an accuracy of $+/-0.02 \mathrm{mS} \mathrm{cm}^{-1}$. The salinity is calculated from the conductivity, water temperature and water pressure in a range from 0 to $40 \mathrm{ppt}$ with an accuracy of $0.02 \mathrm{ppt}$. The current meter has a High Impact Styrene Impeller to measure the current speed in a range of 0.1 to $5 \mathrm{~m} \mathrm{~s}^{-1}$ with an accuracy of +/$2.5 \%$ of reading above $0.5 \mathrm{~m} \mathrm{~s}^{-1}$ and $+/-0.01 \mathrm{~m} \mathrm{~s}^{-1}$ below $0.5 \mathrm{~m} \mathrm{~s}^{-1}$. The current direction is measured using a flux gate compass with a range from $0-360^{\circ}$ with a resolution of $0.5^{\circ}$. The sampling period started at 10:30 AM of January $15^{\text {th }} 2004$ and ended at 11:18 next day. Local meteorological variables, as relative humidity, wind intensity and air temperature, were also measured.

The velocity vector was decomposed in a flood $(\mathbf{v}>0)$ and in an ebb component $(\mathbf{v}<0)$. For the classification of the estuary according to the Stratification-circulation diagram [9], it was assumed laterally homogeneous and a stationary condition was simulated by temporally averaging the measured time series during the time interval of 25 lunar hours. In order to perform the computation, the survey period was divided in two independent tidal cycles (12.41 hours each). The classification is performed computing the stratification (ratio of the surface to bottom difference in salinity divided by the crosssectional average salinity) and circulation (ratio of the net surface current divided by the mean cross-sectional velocity) parameters.

The basis of the classification is the relative contribution of advection and diffusion to the transport of salt in the estuary. An estuary where salt transport is achieved by advection is much better flushed than one which relies only on diffusive processes. Defining the parameter $v$ which is the fraction of horizontal salt transport caused by diffusion and is given by,

$$
v=\frac{\rho K_{H_{0}} \frac{\partial S}{\partial X}}{\rho U_{f} S}
$$

where $K_{H O}$ is the turbulent diffusion coefficient, $X$ is the axial direction, $\rho$ is the density, $S$ is the salinity and $U_{f}$ is the velocity due to the river discharge. If $v=1$, there is no gravitational circulation and the diffusion dominates, if $v=0$ the turbulent diffusion becomes less important and the advection dominates [9].

The Vouga river flow value concurrent with the survey was estimated. Measurements of current velocity were obtained several $\mathrm{km}$ upstream from the anchor station, 3 hours after the low tide hour predicted for the lagoon's mouth. This procedure guarantees that the measurements of current speed were made outside the region of tidal flood influence. The current velocity data were collected using the Valeport current meter model 105 previously referred. In order to compute the flow, the river section was divided in twenty four segments of $2 \mathrm{~m}$ each and the current velocity and the water depth measured for each segment. The current velocity was sampled at $60 \%$ of the water column following a 
standard procedure. The total river flow was obtained adding all individual segment results.

\section{FIELD RESULTS}

\section{Climate, winds and precipitation}

The Vouga River estuary is located in the central area of Ria de Aveiro. The climate of this region is classified as subtropical, since the average temperature is higher than $10^{\circ} \mathrm{C}$ in more than 8 months of the year. The wind regime is characterised by north-western winds during the Summer and a more variable wind regime in the Winter with strong fluctuations in direction and intensity [10]. The annual average precipitation in Aveiro region is about $913 \mathrm{~mm}$ [11]. 75\% of the precipitation occur during the first semester of the hydrological year (October to March), while 25\% occur in the summer. The highest precipitation in the Winter is due to the frequent presence of cold and maritime polar air masses which originates low pressures over the Atlantic coast. In the Summer, the displacement of the Azores Anticyclone to highest latitudes creates a blocking situation affecting the arriving of the precipitation through the north [12].

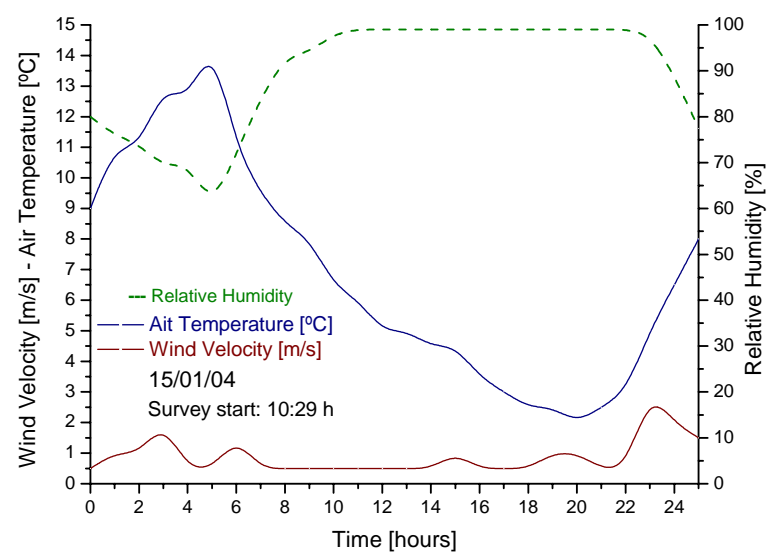

Figure 2. Time serie of air temperature, relative humidity and wind velocity for the sampling period

The sampling campaign was realized under low precipitation $(1.1 \mathrm{~mm})$ and weak wind regime $\left(<2.2 \mathrm{~m} \mathrm{~s}^{-1}\right)$. The air temperature ranges between $14^{\circ} \mathrm{C}$ (daily maximum) and $2^{\circ} \mathrm{C}$ (daily minimum). The relative humidity ranges between about $65 \%$ during the day and almost $100 \%$ during the night, as would be expected. A resume of the meteorological information regarding the sampling period is depicted in figure 2.

\section{Currents and hydrology}

The results of the temporal evolution of the current velocity, salinity and water temperature obtained during the sampling period (figs. $3 \mathrm{a}, 3 \mathrm{~b}$ and $3 \mathrm{c}$ ) indicate that the estuary is forced by semi-diurnal tides. In Ria de Aveiro, the tidal forcing is mainly due to the $M_{2}$ tidal constituent, which has a period of about $12.41 \mathrm{~h}$ and represents almost $90 \%$ of the tidal energy [3]. The sampling period occurred in a neap tide period with tidal range of $1.7 \mathrm{~m}$.

The lunar hourly variation of salinity and water temperature during the sampling period reveals that a stratification/destratification event takes place, due to the interaction between the tide and the river runoff. In fact, as it may be observed in fig. $3 a$, the stratification increases during the flood period, reaching its maximum 1 hour before the high water. This behaviour is due to the saline intrusion (higher density) connected with the tidal propagation along Espinheiro Channel which penetrates under the freshwater (lower density) from the river. 

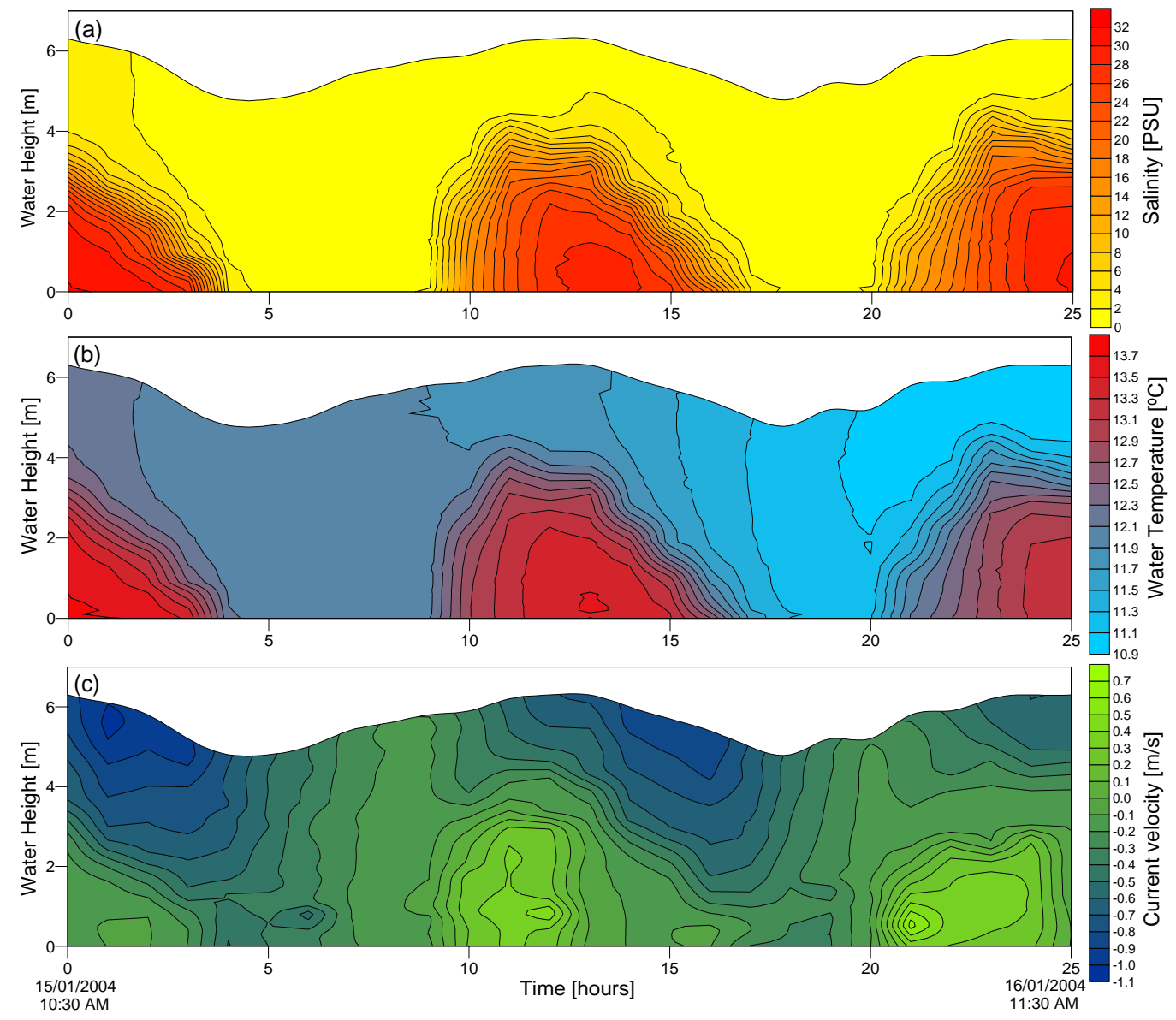

Figure 3. Temporal evolution of (a) salinity, (b) water temperature and (c) current velocity during the sampling campaign

Considering that the high water occurred at the lagoon's mouth at about 08:27 AM (January $15^{\text {th }}$ ), and from the observation of this figure it can be estimated about 2 hours as the time that the tidal front takes to propagate along the $9 \mathrm{~km}$ of this channel until the anchor station location (with a velocity of $4.5 \mathrm{~km} \mathrm{~h}^{-1}$ ). Stratification decreases during the ebb, until the local low water hour. In this phase the entire water column is filled with freshwater propagating from the river, which pushes back the brackish water. Salinity and water temperature values are about 0 psu and $12^{\circ} \mathrm{C}$, respectively.

Near the surface, the water temperature decreases during the day. This is due to the air temperature decreasing (figure 2), influencing the water surface, which transfers heat to the atmosphere. The salinity values are close to the freshwater values ( $0 \mathrm{psu})$ and remain constant during the sampling campaign.

At mid-water, the water temperature has cyclic increased $\left(\sim 1^{\circ} \mathrm{C}\right)$ in the time interval beginning two hours before and ending two hours after the high tide. The salinity has the same kind of behaviour ranging from 20 to 30 psu. In this situation it is observed a typical freshwater salinity value at the surface and a higher value (oceanic water value) near the bottom.

Near the channel's bed, the salinity and water temperature variation has the same pattern that the presented mid-water values, during the sampling period. When the high water is reached the water temperature values are about $14{ }^{\circ} \mathrm{C}$ and the salinity is close to $32 \mathrm{psu}$ (oceanic values). The sampling campaign occurred in early Winter, when the fluvial water temperature is lower than the oceanic one, as confirmed by figure $3 \mathrm{~b}$.

The vertical lunar hourly profiles of velocity (intensity) during the sampling campaign (fig. $3 c)$, indicated an asymmetry between flood $(\mathbf{v}>0)$ and ebb $(\mathbf{v}<0)$. The ebb currents are 
higher than the flood currents, reaching maximum speeds around -1.1 and $0.7 \mathrm{~m} \mathrm{~s}^{-1}$, respectively. The tidal ebbing velocity was enhanced by the freshwater runoff $\left(58 \mathrm{~m}^{3} \mathrm{~s}^{-1}\right)$. Near the surface and at mid-water, the current velocity is always downstream $(\mathbf{v}<0)$, being the surface values higher than the mid-water values.

\section{Estuary Classification}

Nearly stationary conditions were obtained from the time mean salinity and current velocity profiles, for each one of the observed tidal cycles, in order to compute the stratification $\left(\delta S / S_{0}\right)$ and circulation $\left(U_{\text {surface }} / \cup_{f}\right)$ parameters of the classical Stratificationcirculation diagram [9]. The computed parameters were superimposed to the Stratification-circulation diagram as shown in figure 4 . In the first tidal cycle the results were 2.09 and 2.02 for the stratification and circulation parameter, respectively. In the second tidal cycles the values computed for the stratification and the circulation parameters were 1.90 and 2.30 , respectively.

The key parameter $v$ presents values ranging from 0.67 to 0.57 for the first and second tidal cycle, respectively. Assuming the $v$ mean value of 0.62 , the turbulent tidal diffusion and the upstream density-driven flux are responsible for 62 and 38\% of the inward salt flux.

Therefore, assuming no lateral circulation, under early Winter conditions and low freshwater inflow, and accordingly to the Stratification-circulation diagram [9], the upper estuary of the Vouga River was classified as type $2 b$ - partially mixed-highly stratified estuary. The estuary classification remained unchanged in both tidal cycles, as it would be expected, since the characteristics of the tide (neap tide period) and of the incoming river flow $\left(58 \mathrm{~m}^{3} \mathrm{~s}^{-1}\right)$ remained unchanged.
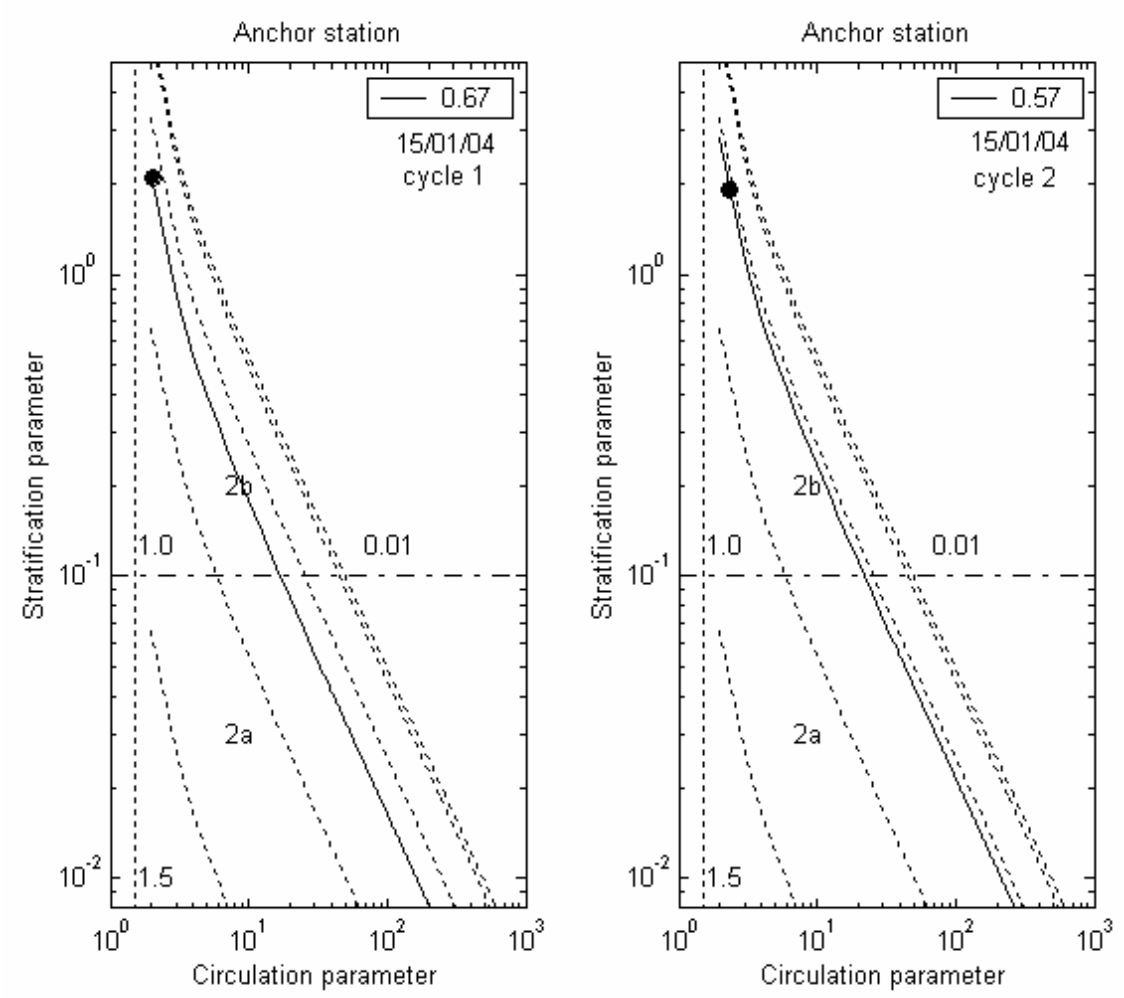

Figure 4. Stratification-circulation diagrams used to classify the fluvial estuary by circulation and salinity structure 


\section{CONCLUSIONS}

These results revealed some of the characteristics of the thermohaline properties, currents and allow the estuary classification in the upper estuary of Vouga River. The observed stratification event was driven by the conjugation of a constant freshwater discharge and of a low saline intrusion associated with the tidal forcing of a neap tide. The salinity and water temperature structure was nearly homogeneous during the low tide, and almost all the rising period, and in this case the water column is essentially composed by freshwater. This behaviour is due to the low tidal currents velocity associated with the neap tide. Vertical stratification was established, during the high tide (two hours before and after) with oceanic thermohaline values near the bottom and at mid depth, and typical river values near the surface.

The observed current velocity asymmetry during the sampling campaign was due to the enhancement of the ebb tidal currents by the freshwater flow, and to the consequent reduction of the flood tidal currents. A similar effect was found by [13] in studying the dynamics of a tropical estuary, the Curimataú River, Brazil.

As final remarks it should be mentioned that the results obtained during this campaign, with specific weather, tidal and river flow conditions, reveal a typically estuarine behaviour. The circulation in a system like Ria de Aveiro is determined by the interaction between the tide and the river flow.

In early Winter conditions, under low river runoff and neap tide conditions, the estuary was classified as type $2 b$ - partially mixed-highly stratified estuary.

\section{REFERENCES}

1. Cameron, W.M. and Pritchard, D.W. (1965), Estuaries, in The Sea, Vol. II, John Willey, New York.

2. Kjerfve, B. (1989), 'Estuarine geomorphology and physical oceanography'. In: Physics of Shallow Estuaries and Bays. J. van de Kreeke. Spring Verlag.

3. Dias, J.M., Lopes, J., Dekeyser, I. (1999), 'Hydrological characterisation of Ria de Aveiro , Portugal, in early summer', Oceanologica Acta, 22 (5), 473-485.

4. Dias, J.M. (2001), 'Contribution to the study of the Ria de Aveiro Hydrodynamics', PhD Thesis, University of Aveiro, Portugal.

5. Vicente, C.M. (1985), 'Caracterização hidráulica e aluvionar da Ria de Aveiro, utilização de modelos hidráulicos no estudo de problemas da Ria'. Jornadas da Ria de Aveiro, III, Edição da Câmara Municipal de Aveiro, Portugal.

6. Borrego, C., Pinho, P., Costa, F., Cardoso da Silva, M. (1990), 'The Case Study of Ria de Aveiro'. Draft report, GRIA, Aveiro.

7. Moreira, M.H., Queiroga, H., Machado, M.M., Cunha, M.R., 1993. Environmental gradients in a southern estuarine system: Ria de Aveiro, Portugal, implication for soft bottom macrofauna colonization. Neth. J. Aquat. Ecol. 27(2-4), 465-482.

8. Dias, J.M., Lopes, J.F., Dekeyser, I. (2003), 'A numerical system to study the transport properties in the Ria de Aveiro lagoon'. Ocean Dynamics, 53, 220-231.

9. Hansen, D.V. and Rattray, M.jr. (1966), 'New Dimensions in Estuary Classification', Limnology and Oceanography, 11(3), 319-326.

10. Fiúza, A.F.G., Macedo, M.E., Guerreiro, M.R. (1982), 'Climatological space and time variation of the Portuguese coastal upwelling', Oceanologica Acta, 5(1), 31-40.

11. Fonseca, J.C., Janica, M.G.R., Proença, M.C.G.F. (1988), 'Panorama no Distrito', VII Jornadas da Saúde de Aveiro, Administração Regional de Saúde, Gráfestal.

12. Manso, M.D.,Dias, J.M., Macedo, F. (1996), 'Aplicación de un modelo de cadenas de Markov de primero y Segundo orden', Avances en Geofísica y Geodesia, 1(1), 151-157.

13. de Miranda, L.B., Bérgamo, A.L., Ramos e Silva, C.A. (2004), 'Dynamics of a Tropical Estuary: Curimataú River, NE Brazil', Journal of Coastal Research, 39, proceedings of ICS 2004, Brasil. (In press). 